Article

\title{
Sustainable urban renewal and densification in China: the case of Suzhou in the Yangtze River Delta region
}

\author{
Paola Pellegrini ${ }^{1, *}$, Jinliu Chen ${ }^{2}$ \\ 1 Xi'an Jiaotong - Liverpool University, Dept. Urban Planning and Design; paola.pellegrini@xjtlu.edu.cn \\ 2 Xi'an Jiaotong - Liverpool University, Dept. Urban Planning and Design; jinliu.chen18@student.xjtlu.edu.cn \\ * Correspondence: paola.pellegrini@xjtlu.edu.cn
}

\begin{abstract}
China is gradually and steadily shifting towards more sustainable development and the local governments are increasingly promoting sustainable spatial planning practices. The article debates the potential contradiction between the goal of a growing urban population and the reduced consumption of land planned by the sustainable development strategy of the city of Suzhou in the Yangtse River Delta region. The article explores the opportunities of densification of the residential urban environment as a possible solution for this contradiction. The article presents some Chinese examples of densification for land use efficiency and identifies in the resettlement communities of Suzhou some of the sites that can be efficiently redeveloped for their obsolescent conditions that do not correspond to the increasingly middle-class status of the residents in the region. The article investigates the different options of densification possible in the resettlement communities in the frame of the policies of urban renewal promoted in China in recent years for improving the urban quality of cities.
\end{abstract}

Keywords: China; sustainable urbanization; densification; Suzhou; resettlement communities

\section{Introduction}

\subsection{The shift in manufacturing in the city of Suzhou}

Suzhou (苏州市) is a prefecture-level city in the Yangtze River Delta region and has greatly developed since the reform of China to realize the socialist market economy and the establishment of the Suzhou Wuzhong Economic Development Zone in 1993 [1].

In fact, in 1990 the Gross Domestic Product of Suzhou was 20.214 billion RMB (US\$ 4.23 billion) and in 2019 it skyrocketed to RMB 1.92 trillion (US $\$ 290$ billion) with a registered foreign capital of RMB 646 billion (US\$ 99.9 billion) and per capita GDP of $\$ 25,900$, ranking third in China. In 1990 the permanent residents in the metro area were 1,067,000 and in 2019 they were 7,070,000 [2].

Urban population growth has followed the economic growth because in China the economic development and city growth are strongly related, and the urbanization rate is a key national priority and one of the greatest drivers of economic, political, social progress [3-6]. The urbanization process transformed farmers into city dwellers and has attracted workforce into the expanding city from less developed areas.

Suzhou is a production hub in the Yangtze River Delta area and the third largest manufacturing city in China [7]. In the future it will keep attracting new inhabitants if it remains competitive and with this goal, the local government city is promoting the rebranding of its manufacturing, that is to say, a shift to creative and innovative productions according to the policy of the Central Government [8]. To realize this shift Suzhou needs to attract the ones who can support this digital empowerment, that is to say, talents and high-level professionals with their families. In fact, according to the report Chinese cities of opportunity 2021, by the China Development Research Foundation, which ranks the main Chinese cities, Suzhou is in a good position for technical maturity, but not for Intellectual capital and innovation. The city has started in 2020 some policies to attract talents 
and to train graduates [9]. Together with these high-skill jobs, the city will attract lowerincome workers such as babysitters, cooks, cleaners, carpenters, health and well-being workers: in fact, every high-skill job produces at least 5 jobs in other sectors [10,11]. These newcomers must find a long-term accommodation that fits their expectations in the city.

\subsection{The shift to a sustainable built environment in China}

In recent years the Chinese Central Government has promoted the New-Type Urbanization for a New Era "beyond mere growth" in the National New Urbanization Plan (2014-2020) 国家新型城镇化规划 [12-14], that supports green and low-carbon development and requires to avoid urban sprawl, low efficiency in land use, the proliferation of useless urban districts, waste of urban space in over-dimensioned infrastructures.

Similarly, the Guidelines on urban planning released in February 2016 by the State Council prohibit expanding cities beyond what their natural resources can support, enforcing urban growth boundaries [15]. To be sustainable, as required also by the environment protection laws issued since 2015, and to save agricultural land for food production, the development of the city should not expand beyond a planned threshold - also known as the "Red Line of China's cultivated land" established by the National Land Planning Outline issued by the Ministry of land and resources in 2009 - and the impermeabilization of the ground should as well be diminished. These notices for preserving agricultural land are combined with the regulation for controlling land supply and the real estate market; since the 2003 year by year the central government established construction land development quotas to every local government different according to the demand-supply situations in different cities [16-18].

In compliance with these national guidelines, the new Master Plan for Suzhou 20202035 is committed to promoting sustainability, preserve natural resources, and stop massive urbanization. The Master Plan does not establish the future threshold of the population growth, differently than in the past, when the development proved that each planned threshold of the total number of inhabitants was under-esteemed [19].

\subsection{A potential contradiction in the development goals}

The growing economy combined with the limits to urbanization can produce a constraint and a contradiction: probable newcomers versus a not expanding city. In a city getting wealthier such as Suzhou not only a problem in quantities can be foreseen, but also a problem in the quality of the built environment: very likely the middle class in Suzhou will keep increasing in number and spending capacity and very likely also the lowincome people will increase their income and consequently their requirements in choosing the family house [20-22].

Suzhou has a high housing vacancy rate- the data is not available, but likely it is around $20 \%$ as in similar cities in China [23-24] - that could be considered for the future demand, but in general the empty stock can not be considered as available for renting because of the investment attitude of the owners: the target of the real estate purchase is the quick and consistent value increase, not the rental returns, that was decreasing to less than $3 \%$ in 2018 [25-27].

Given the premises explained in the previous paragraphs due to the socio-economic progress of Chinese society towards sustainability - a larger population must occupy a limited urban development; a wealthier society requires higher living standards - the research presented in this paper discusses the issue of density starting from the hypothesis that housing quality should rise. If the GDP per capita of Suzhou, as well as its population, keeps growing and at the same time the city wants to avoid sprawl, Suzhou should consider the renewal of some already developed areas, increasing density, the housing offer, and the overall liveability.

\subsection{The structure of the paper}

The paper has the following structure. The Introduction presents the main issues of the research: the growing population in Suzhou and its increasingly middle-class status 
versus the reduction of land consumption for supporting sustainable urbanization. The second chapter explains the reasons for urban densification in high-density urban areas and introduces some Chinese examples. The third chapter investigates the opportunity of densification in Suzhou and presents the resettlement communities as a relevant case study. The fourth and fifth chapters explain some options of densification for the sustainable urban renewal of the communities, combined with the improvement of the quality of the built environment. The last chapter proposes some conclusions about the potentialities of densification.

\section{Growing population and land consumption: high density as a solution}

\subsection{The parameter of high-density}

The parameter Population Density expresses the ratio between the quantity of population that lives in an area and the dimension of the same area. Density alone does not define the urban environment, which is also the result of housing types and compactness, and density in itself is neither a good nor a bad indicator: too much can result in overcrowding and eventual urban decay; too little can deprive the dwelling environment of the chance of social interaction and public transport efficiency [28] (p.7). The definition of density is, nevertheless, closely connected to sustainability because the land is a limited resource: urbanization is "sustainable" when valuable agricultural land is saved and the ecosystem is not jeopardized.

Floor Area Ratio - FAR is the parameter adopted in the regulatory plans in Suzhou to calculate built-up area density: it expresses the ratio between the total built surface and the dimension of the site where the buildings are. FAR varies among the urban areas in Suzhou, and Suzhou as a whole can not be classified as a high-density city: if the rankings of some authoritative institutions are considered - such as the World Atlas; UN-Habitat; Demographia World Urban Areas, the Atlas of Urban Expansion; Global City Power Index [29] - Suzhou does not rank among the densest in the world: the ratio between urban population / urban area in the metropolitan area is roughly less than one-third of the one in Singapore (generally ranked around 10,000 people/sqkm), half the density of Shanghai, that is not ranked in the densest in the world.

The population density in the central district of Suzhou and the 4 adjacent districts (Xiangcheng, Suzhou Industrial Park, Wuzhong, Suzhou New District) was 2,304 People/Sq Km according to the local government in 2019. Demographia World Urban Areas 2019, which considers a smaller area, calculates 3,800 People/Sq Km. These quantities allow us to claim that Suzhou is not a high-density city and to call the recent expansions of Suzhou "high-density sprawl", similarly to the most frequent Chinese urban development mostly realized by series of towers and multi-story buildings in a single-use superblock pattern, that is high-density in comparison to the low-density sprawl of the western world [30-33].

\subsection{Densification for land use efficiency}

Often urban land expands faster than the population grows and in recent years this trend has impacted several Chinese cities, which have experienced declining densities very likely for the rising income leading to the demand for more residential space per capita, and for the restrictions to enter cities due to the policy of the hukou system [34-35]. According to the World Bank even though China has undergone massive urban population growth its urban population density in 2010 was lower than the average of the rest of the East Asia region [36].

Many scholars have presented evidence that higher density in urban areas is associated with a variety of desirable outcomes, including greater environmental sustainability, greater financial stability for local governments, more walkable and healthy living environments, economic development, housing diversity and affordability, enhanced commu- 
nity character, and cultural vitality; but this evidence refers mostly to actions of densification in low-density areas in western countries, not to conditions of higher density as in China [37-41].

Densification means to realize more dwelling units in a given area than in the existing conditions. Generally, it is cheaper and easier - as it requires less design thinking and fewer construction phases - to add new housing at the urban fringes than it is to build in already built-up areas, but over the last 2 decades the idea of urban densification has been explored in several large cities, also the ones that are already medium or high density citywide [42-45] (pp. 132). These densification projects are promoted mainly for the following reasons:

1. the high value of the land combined with the high demand for housing is a potential profit for the developer if what exists is demolished and rebuilt at higher density,

2. the available buildable land is either scarce for geographical conditions or limited by the local regulation for saving agricultural land.

Both reasons justify the actions of densification promoted in already dense cities, such as Paris [46-49], Seoul [50-52], Rotterdam [53-55] or London [56-58]; policies and projects differ among cities because they adapt to local conditions, including the local sociocultural approach to dwelling.

\subsection{Densification in high-density cities in China}

Actions for densification have already been taken in China: in 2003 the "prohibition of land supply for villas" was issued to stop low dense developments by the Ministry of Land and Resources. Over the next decade, the rule had to be repeated five times because it was not fully implemented. In 2019, the Ministry of Housing and Construction issued an urgent notice requesting the suspension of the approval of villa projects and the sorting out of "villa developments built, under construction, under approval and special approval"; subsequently the prohibition - that limits the minimum FAR - was extended to all low-density typologies such as villas, double family row-houses less than 4 story, and townhouses.

The "prohibition of villas" in recent years is justified by the fact that China's arable land has and is sharply decreasing. At the end of 2017, China's cultivated land area was 2.023 billion mu; the National Land Planning Outline required in 2006 that by 2020 the amount of cultivated land would be maintained at 1.865 billion $\mathrm{mu}$, regulation concerning the "Red Line of China's cultivated land", already mentioned in paragraph 1.2, which has the goal to keep the cultivated land area within the quantity planned. The goal of $1.8 \mathrm{mu}$ in 2020 was achieved thanks to the definition of the quotas of construction land, and in the future, the cultivated land area is still set at 1.8 billion mu [59].

Beyond the prohibition of low-density developments and the introduction of the Red Line, in some Chinese cities processes of densification are happening, two very relevant cases are Shenzhen and Shanghai.

The city of Shenzhen is running out of land supply for development: only $2.23 \%$ of the 195,284 hectares of the city is still available for development and real estate prices have skyrocketed. Therefore Shenzhen is demolishing and densifying some already high-dense residential areas which offer bad living conditions. This phenomenon interests mostly the "villages in the city", where in the ' 80 s after the opening-up the original one-story buildings were extruded to several stories and almost to the whole lot, forming in several stages a hyper-compact tissue of what are called "handshake" streets [60, 61]. An example of this process of densification is the Dachong village. The area used to dwell 931 families in 1400 buildings on 69 ha (13,5 families per ha), but in 2011 the whole village was demolished and the reconstruction changed the building type and increased the density from 1.1 million sqm to 2.8 million sqm and 7382 residential units (107 units per ha). The transformation increased as well the land uses, from only residential to a mix-use condition [62].

Investments in urban renewal projects like Dachong are increasing year by year, their proportion on the total reached $16.7 \%$ in 2016 . These actions of densification can be controversial because often they start gentrification, but the promoters claim they need to 
remove the current population for re-qualifying the built environment and increasing the density [63, 64].

In Shanghai, beyond the transformations of the Shikumen, where the FAR of the lowrise high-density houses has been generally increased, densification has been happening mostly along the metro lines and along some central streets in recent years, as an example in the Hengshan area where towers have substituted the original urban tissue [65].

Also resettlement communities are impacted by interesting examples of densification: at the edges of the communities high rises fill empty lots - such as the "Vertical courtyards apartments" in Hangzhou by Wang Shu [66] and the project "The third space" in Tangshan Hebei Province by Li Xinggang [67] - or entire parts are demolished and rebuilt such as the case of Tuanjie Village in Kunshan, Jiangsu Province. A trend of increasing the FAR of the resettlement communities can also be noted in time in Suzhou after 1999: the communities get slightly denser than the previous ones (see the following paragraphs).

\section{The obsolescence of the existing resettlement communities}

The research explores the possibilities of densification in Suzhou, to accommodate a larger quantity of population of different incomes and consume less agricultural land for urbanization; the main research question is: where and how are transformations with densification suitable and effective? The research has focused on the numerous resettlements communities in Suzhou for several reasons: they spread all over the municipality, they occupy already urbanized land, they house a large population, they are becoming obsolete, some of them are low-density.

Resettlements communities or villages are where the farmers who lived in the demolished villages were relocated by the government. In fact, the urbanization process of Suzhou that started in the ' 90 s demolished a large number of rural villages and the inhabitants were resettled in urban communities built cheap and fast for this purpose [68-72].

The research has identified 176 resettlement communities in a $50 \mathrm{~km}$ diameter area centered in the old town and involving all 6 districts of Suzhou (Gusu, Xiangcheng, Suzhou Industrial Park, Wuzhong, Wujiang, Suzhou New District). They were built since 1994, occupy more than 2200 ha, and count almost 360,000 units with estimated around 1 million people, but their population is floating as these communities include a large percentage of immigrants. The average number of units is around 2000, the largest community has 14.000 units and the smallest 112 units.

Official data about the resettlement communities are not available. A general survey of the resettlement communities was conducted with site visits and GIS analysis of the built stock, the green spaces, the mobility system using satellite images from 3 platforms: Google Earth; Baidu maps; 苏州地图, the official website of the Suzhou Natural Resources and Planning Bureau [73]. This analysis defined the essential land-use parameters of every community: the area of the occupied land, the building coverage, the green coverage, the Ground Floor Area. The data available online on the webpages of real estate agencies allowed to know the year of construction, the total number of units, the minimum and the maximum dimension of the units, the Total Floor Area, and the number of floors of the buildings in the community. NOTE 1 


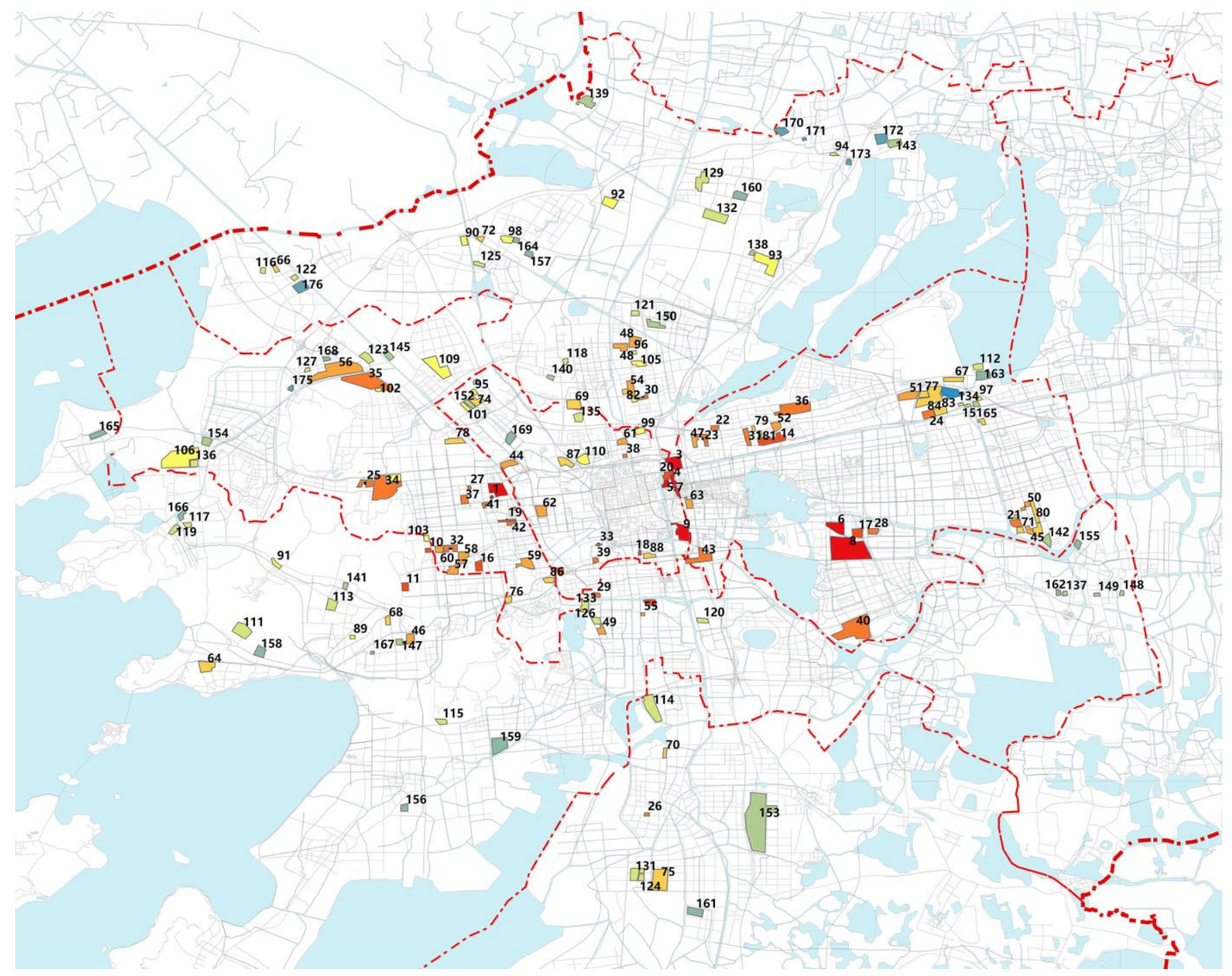

Figure 1. The 176 resettlement communities identified in Suzhou.

The $42 \%$ of the resettlement communities has a Floor Area Ratio between 1.0 and 1.5; the $35 \%$ has a FAR between 1.6 and 2; the $19 \%$ has a FAR higher than 2 ; the $4 \%$ has a FAR lower than 1 . The analysis does not show a general rule in the distribution of the resettlement communities in the city, neither reasons can be found for the different FAR of the cases, if not an higher FAR in proximity to the edges of Gusu, the oldest district of Suzhou, and a lower FAR in the most distant ones from Gusu.

A detailed analysis of the spatial features of 6 communities was carried out, that represent well the characteristic conditions of this kind of settlement in Suzhou. (Figure 2, 3); the communities are:

- Li He Village 里河新村, started in 1994 in Gusu District;

- Nanhuan Community 南环新村, started in 1996 in Gusu District;

- Dengyun Community 登云家园, started in 2000 in Xiangcheng District;

- Lotus Village 莲花新村, started in 2002 in Suzhou Industrial Park;

- Bibo Community 碧波二村, started in 2001 in Wuzhong District;

- Mabang Community 马浜花园, started in 2002 in Suzhou New District. 

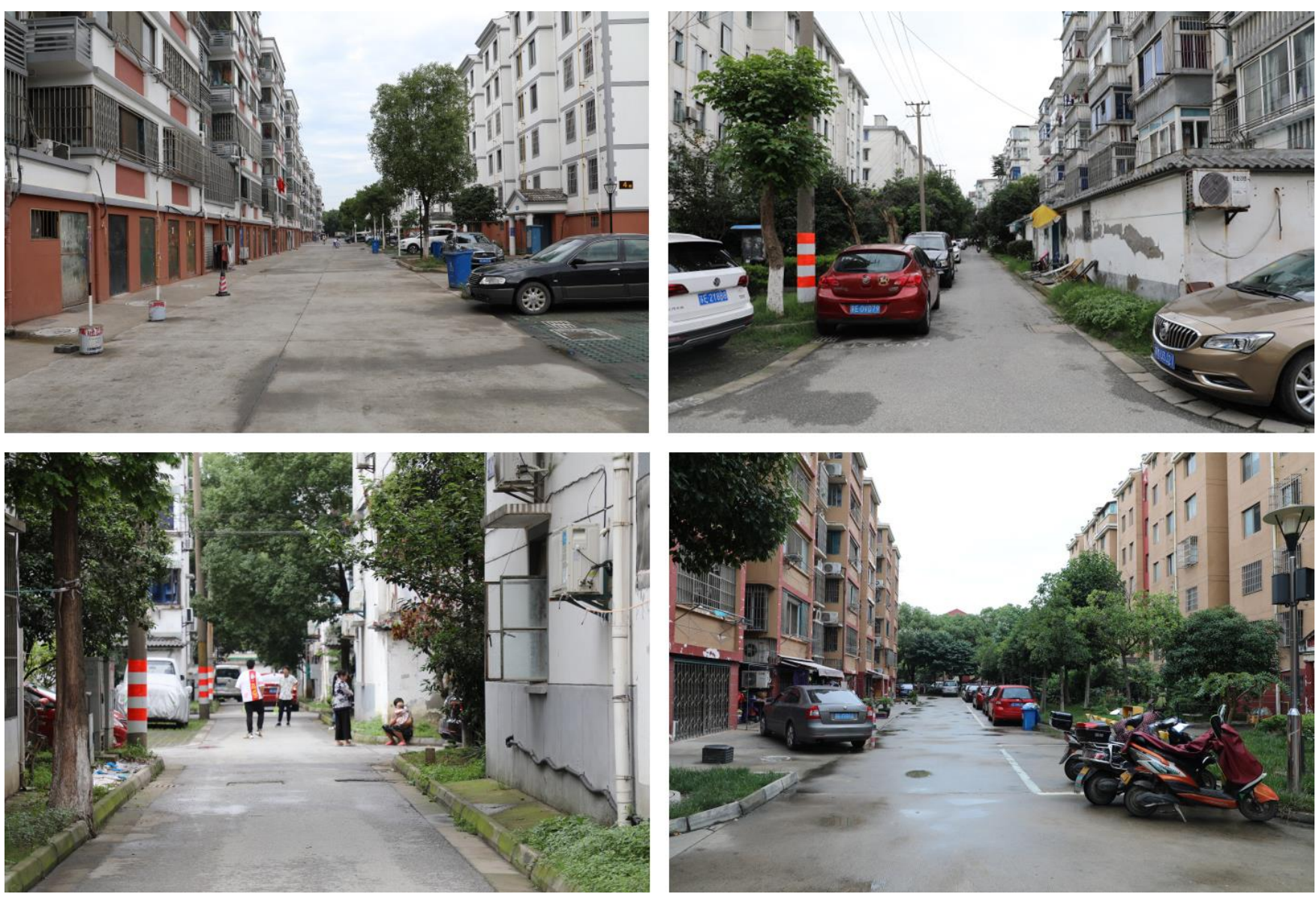

Figure 2. The typical inner courtyards of the resettlement communities.

The analysis of the resettlement communities highlights how some elements and standards are constantly repeated:

- $\quad$ standards in building characters: housing type (multi-story with central staircase and 2 apartments on every floor), number of floors (4-6), depth of buildings (8-12m with verandas);

- $\quad$ standards in the spatial layout: orientation and alignment (east-west), distances between buildings (the minimum allowed to have the sunshine enter the ground floor for at least 2 hours every day according to the regulation), functions (mono-functional: residential with some public facilities for gathering), dimensions and features of the common open space;

- $\quad$ standards in construction quality in compliance with the local regulations [74].

The analysis of the spatial features of the resettlement communities built in the '90s and '00s has highlighted 3 kinds of obsolescence:

1. Obsolescence of the building structure: the buildings are poorly built and equipment and appliances are outdated; in these conditions when the buildings have more than 15 years - which is often the case of resettlement communities in Suzhou - sewage, plumbing, heating, and cooling systems, supply and consumption of electricity and water, soundproof installations should be updated, thermal insulation should be added. Concerning the duration of the performance of the structures, it must be noted that only in 2001 the Unified Standard for Reliability Design of Building Structures (GB50068-2001) put forward the concept of design service life, and defined the design service life of building structures and structural components in 30 years; recently this service life has been increased to 50-70 years [75]. 

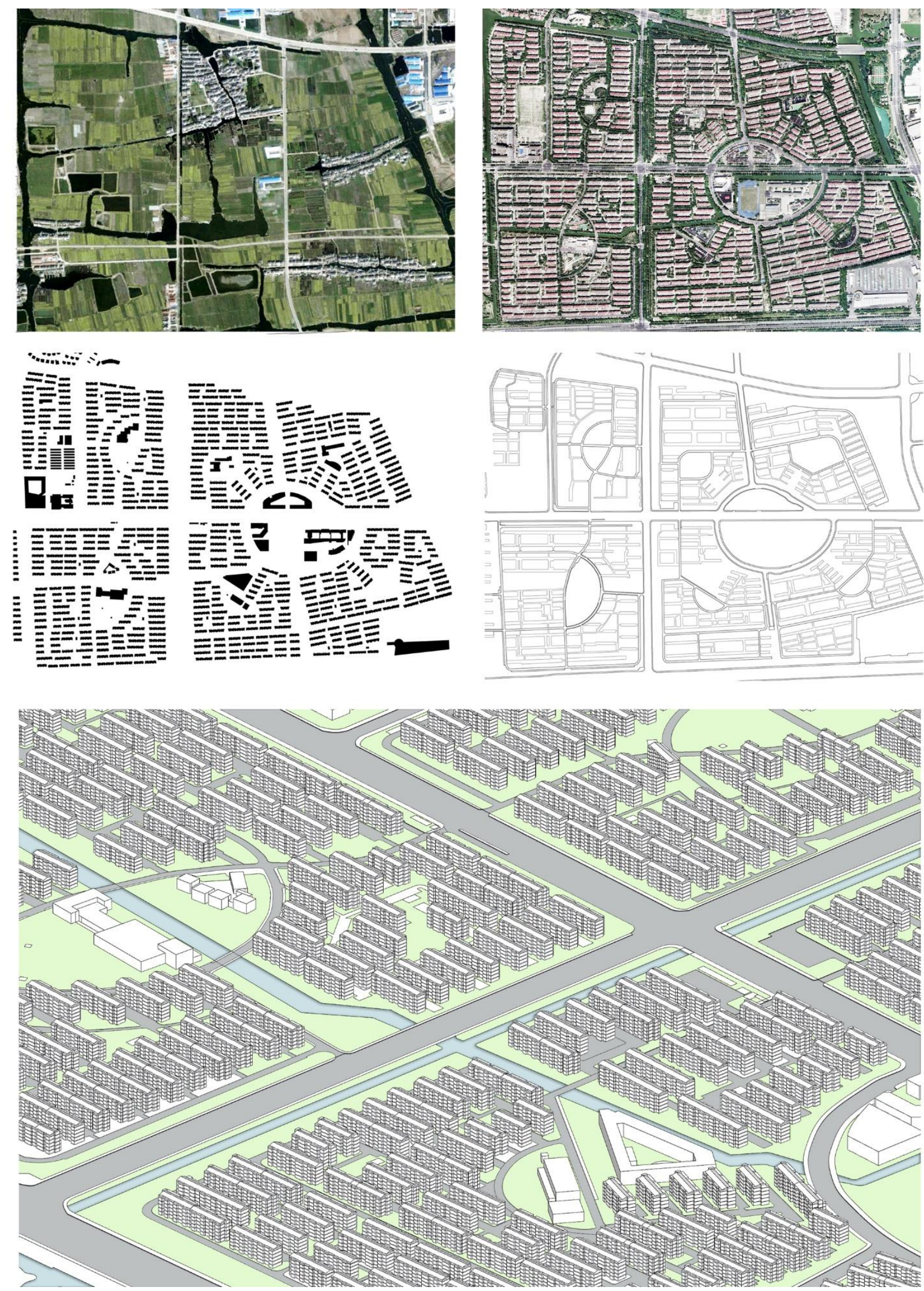

Figure 3. Some representations for the description of the resettlement community Lotus Village, FAR 1.

2. Obsolescence of the living standards inside the units and in the open space: no elevator, no heating, not enough parking space (often the communities were designed 
without parking areas, that were added later transforming green areas), un-differentiated units, limited privacy; in general the units are not small (average minimum gross surface $65 \mathrm{sqm}$, average maximum $125 \mathrm{sqm}$ ), but no unit has a comfortable kitchen with dishwasher and two bathrooms with washing machine, some units are very small: the smallest units are 38-42 sqm gross surface. To deal with these problems the local government has started to imagine some transformations; as an example last October 2018 it has issued the "Suggestions on Adding Elevators to Existing Multi-storey Residential Buildings in Suzhou" to improve the liveability of the existing houses [76].

3. Obsolescence of the urban design and image: both the buildings and the layout of the settlements are "copy-paste", that is to say, they were built using the same materials, the same low building technology, and the same not site-specific design. The future moderately prosperous society - as envisioned by the Leaders of the Chinese Partywill require a good design of the building as well as of the open space, which means also the mixing of uses - that is rarely allowed in current communities - and diversified housing types for diversified lifestyles and household (large families, small families, singles, empty-nest couples, temporary city dwellers, co-habitants).

\section{The resettlement communities as an opportunity for renewal}

In a fast-changing China, where the middle-class is rapidly increasing and consumption is encouraged, and especially in Suzhou, that wants to shift to creative and innovative productions and attract talents [77], the existing obsolescent resettlement communities originally built for farmers and families with a low income - will not be considered housing environments able to provide an up-to-date standard of living in the near future. For the obsolescence on one side, and the improvement of economic conditions on the other side the resettlement communities can be considered a part of the city to renew.

This idea of renewal is coherent with the guidelines of the national government, that in the 14th 5-year plan 2021-2025 for national economic and social development of the People's Republic of China and in the Outline of long-term goals for 2035 for the first time has officially promoted an urban renewal approach for the improvement of the existing built environment next to the usual large-scale incremental development. The plan is supporting the renewal of the communities built before 2000 and the policy of regeneration that targets the "three-old" - that is the old village, the old town, the old factory - for "encouraging intensive land use", that started in the Guangdong Province in 2008 and spread to the whole Country [78-79]; Suzhou is included in the demonstration sites for old town renewal.

In this transformation, densification can be taken into consideration to give a house to more and diversified inhabitants and increase the land-use efficiency. The analysis of the parameter of density of the 176 resettlement communities in Suzhou shows a small trend of densification in time: in the early years of urbanization the units were smaller and FAR was lower, less than 1.3; the cases with a FAR higher than 1.5 are realized after 1999, but in the '00 FAR higher than 2 and lower than 1.5 coexisted. After 2008 almost no communities have a FAR lower than 1.5. From 2016 almost all cases have a FAR higher than 2 , reaching also more than 3 , and units get larger.

The 6 communities analyzed in detail have a Floor Area Ratio that ranges from 0.95 to 1.75 , on average 1.27 , while the average FAR of all 176 cases is 1.73 , the minimum is 0.7 and the maximum is 3.87 .

The highest FAR is in Nanhuan New Town 南环新村-新, Gusu District, which is the only case in Suzhou of the regeneration with densification of a resettlement community, Nanhuan Community 南环新村, originally built in 1996 on agricultural land. In 2013 the former community was partially demolished and rebuilt with a different housing type, the high rise, a different layout of open space and green areas, and a FAR more than three times the former one, that was 1.1. Table 1 compares the main characters of the traditional resettlement village in Suzhou with Nanhuan New Town. 
Table 1. Comparison of the average of the main characters of the 6 resettlement communities analyzed in detail with the densified community, Nanhuan New Town.

\begin{tabular}{ccc}
\hline & Average of 6 case studies & Nanhuan New Town \\
\hline FAR & 1.27 & 3.87 \\
Housing type & multi-storey & high-rise \\
Number of floors & $4-6$ & $28-32$ \\
Green coverage & 0.35 & 0.25 \\
Construction cost & $1200 \mathrm{RMB} / \mathrm{sqm}$ & $2500 \mathrm{RMB} / \mathrm{sqm}$ \\
Car Parking & No structures nor areas for & Underground parking, \\
& parking in the original & 0.8 car parking for every unit \\
& master plan; parking was & \\
& obtained in recent years in & \\
& the green spaces. & \\
Comfort & No elevator & Elevator \\
& No heating nor air & Heating and air conditioning \\
& conditioning & \\
& No soundproof walls & Soundproof elements \\
& No thermal insulation & Thermal insulation \\
& Fragmented open space & Continuous open space \\
\hline
\end{tabular}

\section{Options of redevelopment and densification}

If the resettlement villages are chosen as targets for redevelopment and densification because of their characters, what cases should be selected and why? How can they be transformed? The paper proposes three options of densification and evaluates their possible significance.

1. Renewal and densification of all the resettlement community.

Some general and abstract considerations can be advanced. If all the resettlement villages in Suzhou were densified duplicating the Floor Area Ratio, it would mean to double the inhabitants, so the total number of people would double by 1 million people. In a strategic approach, once the action of densification is decided, it is advisable FAR be higher than double, as in the Nanhuan New Town example that is three times the original FAR.

If the replacement happened in the whole Suzhou the impact would be very relevant in quantity but also quality. In fact replacing the existing buildings, which were modern when the first inhabitants arrived, but today are - or soon will be in middle-class China - obsolescent, goes along with the challenge of the definition and implementation of a new standard of residential environment promoted by the state: in fact as what was good enough for just resettled people was decided when the resettlement operations started, so should happen today when new conditions emerge. The large investment needed for the replacement must increase the number of people in the same area but also:

-enhance the open spaces in quantity and quality: larger and less scattered and fragmented open spaces would be a good improvement;

-improve the mobility for cars as well as for people, designing roads and parking places clearly separated from the pedestrian and bike network;

-improve the accessibility with a more permeable system of gates;

-diversify the units to match the needs of the different households and new lifestyle preferences;

-diversify the housing types: higher density housing does not automatically require high rise developments; 
-mix land use to create a "sense of place" and an attractive street life for pedestrians; -include sustainable efficiency augmentation, such as devices for renewable energy, and the "sponge city" transformations, such as rainwater retention and cleaning.

2. Selection of cases according to indicators of the intensity of land use.

If the transformation of all the resettlement communities is hardly feasible for its social and economic costs, some rationalities for selecting what communities to densify can be proposed, together with a process of gradual transformation in the mediumterm according to the existing policies.

The project of densification should be site-specific and take into account multiple factors, that is to say, each specific redevelopment can define how to optimize the FAR in the re-design of the site, but some general conditions where densification should happen can be identified. Renewal and densification should be proposed in the resettlement communities which

- do not use efficiently the land they occupy because the FAR is much lower than the average of the communities: the ones where FAR is lower or equal to 1 (8 cases) should be the first to be renewed; the ones with FAR lower or equal to 1.2 (18 cases) should be considered as the second group. In total the communities with FAR lower or equal to 1.2 now accommodate almost 128,000 people in 40,423 units;

- were built before 2000 (12 cases), as proposed by the national guidelines, which now accommodate almost 78,000 people in 25,956 units;

- are next to metro stations or transport interchanges (within $400 \mathrm{~m}$ from one of the gates of the community) and have a FAR lower or equal to 2 to fully exploit the transport capacity and accessibility the site has. The most proper threshold of FAR should be defined by specific projects according to the local conditions and the transport capacity.

The analysis of the available GIS data of the built fabric and the public transit infrastructures allows us to determine which resettlement communities are both low density and with gates in a radius of $400 \mathrm{~m}$ from a subway gate or a bus interchange or a terminal, see Figure 4. 


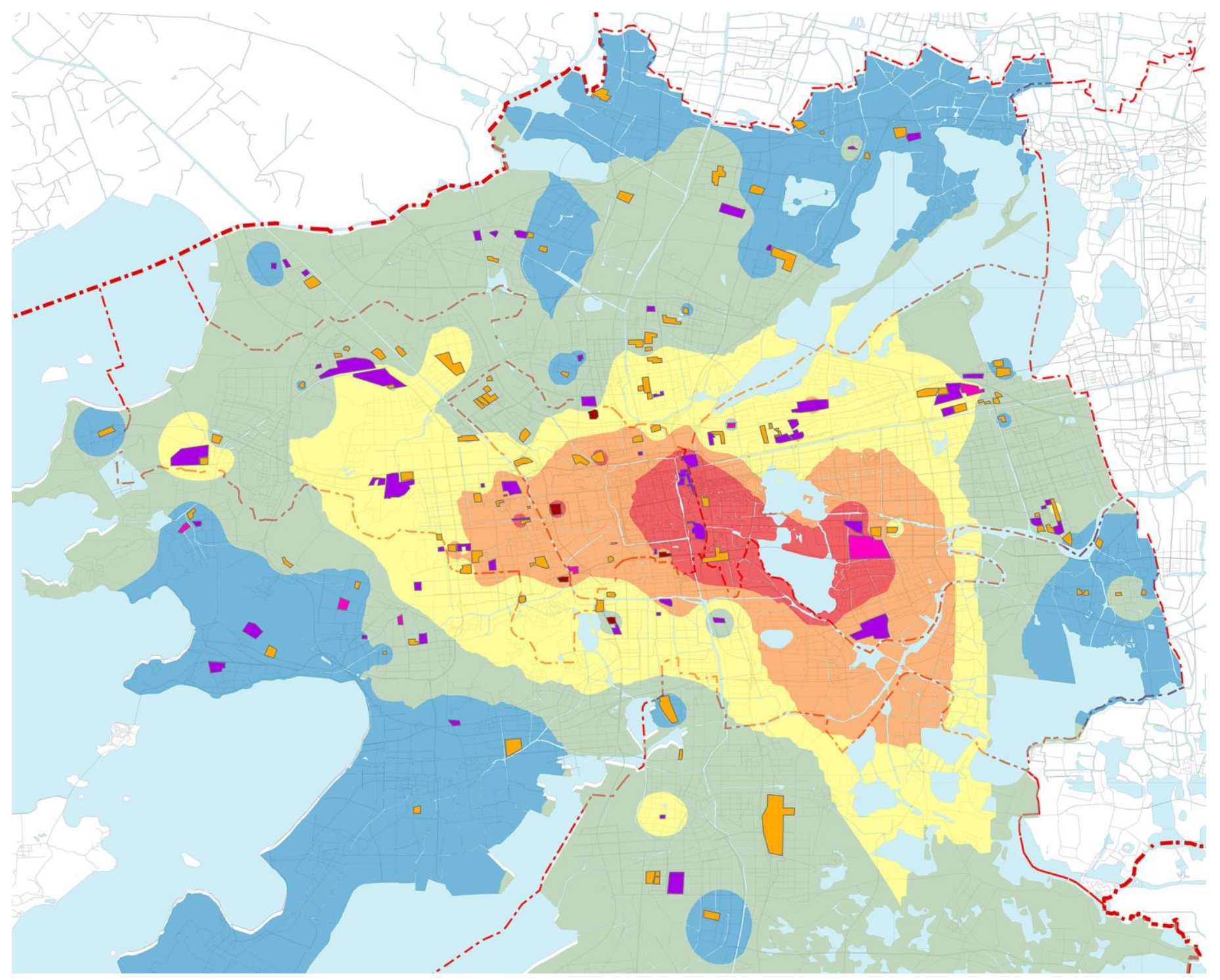

Figure 4. GIS spatial analysis of the resettlement communities and the areas with different accessibility (bus stops and subway stations): the low-density communities in the orange and red areas that have the best accessibility in Suzhou can be considered for urban renewal with densification.

These first groups can be pilot projects to test potentialities and obstacles to realize the optimum potential of sites: to what extent the FAR can be increased must be assessed in the local context and multiple factors must be taken into account, including social infrastructure [56].

Other indicators can be considered to propose a renewal of the community, such as the quantity and quality of the open and recreational space: the communities that have a building coverage higher than $25 \%$ and a green coverage less than $30 \%$ - which means the open area of the community is mostly for mobility - should be investigated to assess the quality of the open space they offer combined with the FAR.

If this renewal happened the value of the redeveloped estate would exceed the original value of the estate plus the cost of change, which is the expense, the temporary problems for the inhabitants, the impact on the environment for the demolition and rebuilding. The upheaval of people's lives and improvement of living conditions should be included in the viability assessments and some form of subsidy should be provided. Local processes of public participation should be organized to inform the inhabitants and discuss the project. The assessment of increased density should be in relation to the perception of the urban environment from the inhabitants and high density must avoid extreme conditions of living [37]. 
3. Densification of the existing structures.

Solutions of densification which maintain the existing structures, when these are in good conditions, can be designed. The examples of Seoul and Rotterdam show it is possible to infill, build over, build in-between existing buildings, and even though these actions can not increase substantially the number of people in the communities, they invest a small amount of resources, do not demolish the houses of the ones who have already experienced one resettlement, reduce the impact of reconstruction on the environment.

These punctual actions of densification must be defined by specific projects and their contribution to the whole city housing offer can not be esteemed without a general plan that sets goals and targets. These kinds of actions indicate that to grow denser might be to build a compact city, not a super-density city [80-82]; might be to realize different housing types than the ones usually built in Suzhou, such as the compact superblock. A research-by-design or a design competition for new housing types in Suzhou should be promoted.

\section{Conclusions}

In conditions of a growing urban population, the intensity of land use is an essential planning decision in promoting sustainability. Chinese local governments are increasingly encouraging compact and mixed-used developments mainly to maximize land revenues and capture commercial and residential land value [83], not yet to balance economic landed interests and sustainability purposes, but the planning approach in the Country is gradually and steadily shifting towards more sustainable development and urban environment. In this process for enhanced use of resources, the redevelopment of some built areas that do not perform efficiently can be considered; in this direction, the Chinese Central Government has promoted the regeneration and renewal of what was built before 2000, which is a huge undertaking because the whole Country is the target.

The research explored the opportunity of densification of what is already built in Suzhou to diminish the consumption of agricultural land and offer a better living environment. The research concluded that some resettlement communities can be the proper sites of renewal with densification; in fact, these communities in Suzhou are quickly deteriorating and offer inadequate services and poor housing conditions if the increased wealth of the population is considered, the more so if the actions for further improving the living conditions the government is working for are successful.

The research has found that the densification of the resettlement communities can have a significant impact on the intensification of the use of land in the whole Suzhou, given the large number of such communities and their low or medium Floor Area Ratio. The project of densification should be site-specific, but a general city-wide plan of interventions should be drafted with priorities and phases: densification should be promoted especially in the resettlement communities with low FAR and good transport capacity and accessibility. The local government should encourage dense and contiguous development and should explicit goals to be respected by every development; what option of densification can be feasible and more proper for each condition can be decided case by case.

Urban redevelopment is costly, and the reconstruction itself uses resources, but it can be convenient for the local government because it concerns old urban areas and therefore it does not occupy agricultural land and it does not consume the land development quotas that the central governments allocate to the local government. In addition to this, the increased redevelopment density contributes to the economic sustainability of the transformation because it can generate sufficient funds for the redevelopment itself and the compensation of the inhabitants, similarly to what already experimented as an example in the redevelopment of the urban villages in Guangdong [84].

The goal of the transformations with densification analyzed and proposed in the research is not gentrification, neither profit nor revenue maximization [85], but another step in the process of improvement of the built environment and land value appreciation, benefits that can be shared with the current inhabitants. 


\begin{abstract}
Author Contributions: Conceptualization, P.P.; methodology, P.P. and J.C.; software, J.C.; analysis and investigation, P.P. and J.C.; resources and data curation, J.C.; writing P.P.; visualization, J.C.; supervision, P.P.; funding acquisition, P.P. The authors have read and agreed to the published version of the manuscript.
\end{abstract}

Funding: This research was funded by Xi'an Jiaotong - Liverpool University, RDF-17-02-25.

Data Availability Statement: The data supporting the research were created by the authors because no publicly and official archived datasets are available about the resettlement communities and their floating population; authors can provide the data and the analysis upon request.

NOTE 1: As the official data about the resettlement communities and their floating population are not available, the data about the resettlement communities are obtained from the webpages of the largest real estate agencies in China: Anjuke lnc, Lianjia.com, and Soufun.com and from what visible in the most updated satellite images; authors can provide the data and the analysis upon request.

\title{
References
}

1. Wang, Y.; Wu, W; Boelens, L. City profile: Suzhou, China - The interaction of water and city. Cities 2021, 112, DOI: 10.1016/j.cities.2021.103119.

2. Suzhou Statistical Yearbook, Available online: https://www.suzhou.gov.cn/szsrmzf/tinj/nav_list.shtml (accessed on 20 January 2021).

3. National New Urbanization Plan of China (2014-2020).

4. National Congress of the Chinese Communist Party, 2017, the report of the President.

5. Wu, F. Planning for Growth: Urban and Regional Planning in China; Routledge, London, 2015.

6. Wesley, E.; Peterson, F. The Role of Population in Economic Growth. Sage Open 2017, https://doi.org/10.1177/2158244017736094

7. Available online: https://www.china-briefing.com/news/suzhou-investment-stronghold-innovation-trailblazer-yrd/ (accessed on 20 January 2021).

8. Xia C. (Director of the Planning Division of Suzhou Development and Reform Commission). Communication "Decode the Suzhou's 14th Five-Year Plan (2021-2025)", at the Urban Planning and Design Department of XJTLU, Suzhou the 24th March 2021.

9. Available online: $w w w . r c s z . g o v . c n$, among the measures: Incentive measures for Suzhou enterprises and institutions to attract and use talents; Suzhou talent happy residence project; High-end Talent Reward; Jiangsu Province Residence Permit for Overseas High-end Talents Reward (accessed on 20 January 2021).

10. Moretti, E. The new geography of jobs; Mariner Books, 2013.

11. Florida, R. The rise of the creative class; Basic Books, 2003.

12. Available online: http://english.www.gov.cn/policies/latest releases/2016/02/06/content 281475285253766.htm (accessed on 20 January 2021).

13. Chen, M. et al. Progress of China's new-type urbanization construction since 2014: A preliminary assessment. Cites 2018, 78, 180-193, DOI: 10.1016/j.cities.2018.02.012.

14. Chen, M.; Liu, W.; Lu, D. Challenges and the way forward in China's new-type urbanization. Land Use Policy 2016, 55, 334-339.

15. Guidelines on urban planning 2016, and Opinions on Further Strengthening the management of urban planning and construction. Available online: http://www.gov.cn/zhengce/2016-02/21/content 5044367.htm (accessed on 20 January 2021).

16. Lin G.C.S. China's landed urbanization: Neoliberalizing politics, land commodification, and municipal finance in the growth of metropolises. Environment and Planning A 2014, 46, 1814-1835.

17. Shena, X. et al. Exploring the relationship between urban land supply and housing stock: Evidence from 35 cities in China. Habitat International 2018, 77, 80-89, DOI: 10.1016/j.habitatint.2018.01.005.

18. Jiang C.; Deng, X.; Seto, K. The impact of urban expansion on agricultural land use intensity in China. Land Use Policy 2013, 35, 33 - 39, http://dx.doi.org/10.1016/j.landusepol.2013.04.011)

19. Miu, Y. (Director of Urban Renewal Center at CAUPD). Communication "The masterplan of Suzhou from 2020 to 2035 and its sustainable development strategy", lecture at the Urban Planning and Design Department of XJTLU, Suzhou the 14th of October 2018.

20. Goodman, D.S.G.; Chen, M. Middle class China: identity and behaviour; Cheltenham Edward Elgar, 2013.

21. Li, Z. In search of paradise: middle-class living in a Chinese metropolis; Cornell University Press, 2010.

22. Chen, C.; Bo, Q. The emergence of China's middle class: Social mobility in a rapidly urbanizing economy. Habitat International 2014, 44, 528-535.

23. Gan, L. et al. Analysis of Urban Housing Vacancy of China in 2017, Southwestern University of Finance and Economics Press, Chengdu, China, 2018.

24. Tan, Z; Wei, D.; Yin, Z. Housing Vacancy Rate in Major Cities in China: Perspectives from Nighttime Light Data. Complexity 2020, 2020, https://doi.org/10.1155/2020/5104578.

25. Available online: https://www.globalpropertyguide.com/Asia/China/Rental-Yields (accessed on 20 January 2021).

26. Huuhka, S. Vacant residential buildings as potential reserves: A geographical and statistical study. Building Research $\mathcal{E}$ Information 2016, 44:8, 816-839. 
27. Hagen, D.; Hansen, J. Rental housing and the natural vacancy rate. Journal of Real Estate Research 2010, 32 (4), $413-433$.

28. Rowe, P.G.; Kan H.Y. Urban Intensities: Contemporary Housing Types and Territories; Birkhauser, Basel/Berlin/Boston, 2014.

29. Available online: www.newgeography.com/content/006272-demographia, Demographia World Urban Areas 15th Annual Edition 2019; https://www.worldatlas.com/articles/the-world-s-most-densely-populated-cities.html; https://www.weforum.org/agenda/2017/05/these-are-the-world-s-most-crowded-cities/; Shlomo Angel et al., Atlas of Urban Expansion, vol.1: Areas and Densities, Lincoln Institute of land Policy 2016, https://www.lincolninst.edu/publications/other/atlas-urban-expansion2016-edition; http://mori-m-foundation.or.jp/english/ius2/gpci2/index.shtml (accessed on 20 January 2021).

30. Monson, K. String Block Vs Superblock. Patterns of Dispersal in China. Architectural Design 2008, 8 (1), https://doi.org/10.1002/ad.608

31. Hassenpflug, D. The urban code of China; Birkhäuser, 2011.

32. Calthorpe, P. Urbanism and Global Sprawl. In Can a City Be Sustainable? State of the World, Island Press, Washington, DC. https://doi.org/10.5822/978-1-61091-756-8_7 91-1082016.

33. Deuskar, C.; Baker J.L.; Mason, D. East Asia's Changing Urban Landscape: Measuring a Decade of Spatial Growth, The World Bank Group, 2015. Available online: Worldbank.org/eap/measuringurbanexpansion (accessed on 20 January 2021).

34. Xua G. et al. How does urban population density decline over time? An exponential model for Chinese cities with international comparisons. Landscape and Urban Planning 2019, 183, 59-67 https://doi.org/10.1016/j.landurbplan.2018.11.005.

35. Modern cities become less dense as they grow. The Economist, 25 October 2019.

36. World Bank data. Available online: https://data.worldbank.org/country/china; https://data.worldbank.org/indicator/EN.POP.DNST (accessed on 20 January 2021).

37. $\quad \mathrm{Ng}$, E. Designing High-Density Cities: For Social and Environmental Sustainability; Routledge, 2009.

38. Clark, G.; Moir, E. Density: drivers, dividends and debates; Urban Land Institute, 2015.

39. Owen, D. Green Metropolis: Why Living Smaller, Living Closer, and Driving Less Are the Keys To Sustainability; Riverhead books, 2010 .

40. Whittemore, A.; Ben Dor T.K. Talking about density: An empirical investigation of framing. Land Use Policy 2018, 72, 181-191

41. The Dense-city. After sprawl, Ray, M.A.; Sherman, R.; Zardini, M., Eds.; Lotus Quaderni Documents 1999.

42. Carbajal, V.; Noé, A. New trends in densification projects within the Million Homes Programme areas, Malmö universitet. Available online: http://hdl.handle.net/2043/26468 (accessed on 20 January 2021).

43. NYC's supertall skyscraper boom. Available online: https://ny.curbed.com/maps/new-york-skyscraper-construction-supertalls (accessed on 20 January 2021).

44. Center for Liveable Cities. 10 Principles for Liveable, High-Density Cities: Lessons from Singapore, Urban Land Institute, 2013.

45. Huang, B.; Peng Beng, K.; l'Heureux, E.; Schaetz, F. 1000 Singapores: a model of the compact city, 2010.

46. Touati-Morel, A. Hard and Soft Densification Policies in the Paris City-Region. International Journal of Urban and Regional Research 2015, 39 (3).

47. Région Île-de-France. Schéma directeur de la Région Île-de-France; Projet adopté par délibération du Conseil régional, 25 Septembre 2008.

48. Available online: https://www.projetsurbains.com/le-forum-des-projets-urbains-2019.html (accessed on 20 January 2021).

49. Available online: https://www.mvrdv.nl/projects/358/grand-paris (accessed on 20 January 2021).

50. Hong Kim, S. The FAR Game: Constraints Sparking Creativity; ART Data, 2016.

51. Jang, M.; Kang, C. Urban greenway and compact land use development: A multilevel assessment in Seoul, South Korea. Landscape and Urban Planning 2015, 143, 160-172.

52. Kramer, S. Design solutions for urban densification; Salenstein, Braun, 2018.

53. Aarts, M.; Tillie, N.; Rijke, C.; Doepel, D.; Lap, S.; Stenhuijs, L. Rotterdam - People Make The Inner City; The 5th International Architecture Biennale Rotterdam (April - August 2012).

54. Broitman, D; Koomen, E. Residential density change: Densification and urban expansion. Computers, Environment and Urban Systems 2015, 54, 32-46.

55. Claassens, J.; Koomen, E. Housing trends in the Netherlands: Urban densification continues. Vrije Universiteit Amsterdam, 2017. Available online: https://spatialeconomics.nl/en/housing-trends-the-netherlands-urban-densification-continues/ (accessed on 20 January 2021).

56. Greater London Authority. The Density of New Housing Development in London. Executive Director of Secretariat, 25 February 2014.

57. Available online: https://www.london.gov.uk/what-we-do/planning/london-plan/current-london-plan/london-plan-chapter3/policy-34-optimising (accessed on 20 January 2021).

58. Hanna, K.; Oduwaiye, A.; Redman, P. Another Storey: The Real Potential For Estate Densification, Center for London, 2016. Available online: https://www.centreforlondon.org/publication/estate-densification/ (accessed on 20 January 2021).

59. 14th five-year Plan (2021-2025) for for National Economic and Social Development of the People's Republic of China.

60. 建筑实践 I| 2020年第11期 II 深圳城记, 实践冊年.

61. Al, S. Villages in the City: A Guide to South China's Informal Settlements, University of Hawaii Press, 2014.

62. Southern metropolis daily 2010, the related real estate agency. Available online: https://wenku.baidu.com/view/270658eb6bec0975f465e2c6.html, last accessed January 2021 (accessed on 20 January 2021).

63. Chen, T. State beyond state, Shenzhen and the transformation of urban China, Nai010 publishers, 2017.

64. 孟春云, 高层住宅, 高容积率经济适用房建设的趋势和问题, 2011. 
65. Pan, X.Z. et al. Analyzing the Variation of Building Density Using High Spatial Resolution Satellite Images: the Example of Shanghai City. Sensors 2008, 8 (4), 2541-2550; https://doi.org/10.3390/s8042541

66. Available online: https://www.archdaily.com/211962/wang-shus-work-2012-pritzker-prize/page23c vertical courtyard apts/(accessed on 20 January 2021).

67. Available online: https://www.archdaily.com/885601/the-third-space-atelier-li-xinggang/(accessed on 20 January 2021).

68. Chuang, J. Urbanization through Dispossession: survival and stratification in China's new townships. Journal of Peasant Studies 2015, 42(2), 275-294.

69. Wu, F. Residential relocation under market-oriented redevelopment: The process and outcomes in urban China. Geoforum 2004, 35(4), 453-470.

70. Jiang, Y.; Waley, P.; Gonzalez, S. 'Nice apartments, no jobs': How former villagers experienced displacement and resettlement in the western suburbs of Shanghai. Urban Studies 2018, 55(14), 3202-3217, DOI: 10.1177/0042098017740246.

71. Gomersall, K. Resettlement practice and the pathway to the urban ideal. Geoforum 2018, 96, 51-60 https://doi.org/10.1016/j.geoforum.2018.07.018Ge.

72. Xu, Y.; Tang, B.; Chan, E.H.W. State-led land requisition and transformation of rural villages in transitional China. Habitat International 2011, 35, 57-65 doi:10.1016/j.habitatint.2010.03.002.

73. Available online: http://www.map512.cn/index.php (accessed on 20 January 2021).

74. Technical regulations on urban planning management of Jiangsu Province, Sunshine impact analysis rules, technical regulations for planning and design of residential areas in Suzhou Industrial Park 江苏省城市规划管理技术规定苏州市实施细则之二 ;“日照影响分析规则”; 关于印发《苏州工业园区住宅区规划设计技术规定》的通知).

75. 2001 年, 《建筑结构可靠度设计统一标准》(GB50068- 2001) 首次提出了设计使用年限的概念, 明确了建筑结构和结构构件的设 计使用年限.

76. Available online: https://www.suzhou.gov.cn/gzcy/myzj/mydc/lfzqyj/201810/t20181029 $1011744 . \operatorname{shtml}$ (accessed on $20 \mathrm{Janu}-$ ary 2021).

77. Li, Z. (Dean of the Suzhou Government research institute). Communication "Orientation of Suzhou under the background of regional integration in the Yangtze River Delta", at UPD XJTLU, 9 April 209.

78. Li, F.; Huang, H. The "Three-Old" Policy of Community Renewals in China: Based on Cases in the Pearl River Delta Region, Conference proceeding of the 49th ISOCARP Congress 2013.

79. Li, X. et al. From Habitat III to the new urbanization agenda in China: Seeing through the practices of the "three old renewals" in Guangzhou. Land Use Policy 2019, 81, 513-522, https://doi.org/10.1016/j.landusepol.2018.11.021.

80. Dempsey, N. Revisiting the compact city? Built Environment 2010, 36, 5-8.

81. Jenks, M. Achieving sustainable urban form. E \& F.N. Spon, London and New York, 2000.

82. OECD (Organisation for Economic Co-operation and Development). Compact city policies a comparative assessment. OECD, Paris, 2012. Available online: http://www.oecd.org/greengrowth/compact-city-policies-9789264167865-en.htm (accessed on 20 January 2021).

83. Wu, F. Planning centrality, market instruments: Governing Chinese urban transformation under state entrepreneurialism. Urban Studies 2018, 55(7), 1383-1399.

84. Li, B.; Lui, C. Emerging selective regimes in a fragmented authoritarian environment: The 'three old redevelopment' policy in Guangzhou, China from 2009 to 2014. Urban Studies 2018, 55(7), 1400-1419.

85. Wu, F. State dominance in urban redevelopment: Beyond gentrification in urban China. Urban Affairs Review 2016, 52, 631-658. 